\title{
Innovation now
}

\author{
David Payne digital editor
}

The BMJ

Eight thousand taxis gridlocked central London last week as drivers protested at the rise of the cab hailing app Uber, ${ }^{1}$ the latest in a series of similar demonstrations in the UK and other cities around the world. Opponents claim that Uber undercuts traditional licensed cabs and is less regulated. But can Uber's technology be successfully applied to medicine? Nigel Hawkes (10.1136/bmj.i771) reports on the emergence of companies claiming to be "the Uber of healthcare" and asks whether such innovation will ultimately reinvent home visits, which in the UK now account for less than one in 25 GP consultations. This reinvention includes private paid "virtual" home visits, as Ingrid Torjesen outlines $(10.1136 / \mathrm{bmj} . \mathrm{i} 823)$. Is there a market in the UK? Many have their doubts, but the kidney specialist Renee Dua, founder of the US startup Heal, which in its first year has treated 2000 patients in Los Angeles and Orange County, says that the Uber model can be applied globally.

London taxi drivers were not the only ones demonstrating last week. Gareth Iacobucci's live blog covered the junior doctor strike across England (bmj.co/strike) and the subsequent contract imposition by England's health secretary, Jeremy Hunt. Our GP columnist Margaret McCartney (10.1136/bmj.i909) accuses Hunt of choosing the nuclear option and jeopardising the "moral contract" between clinicians and patients, effectively setting the NHS up to fail. As far as primary care is concerned, she warns: "It's easy to see how the proliferating private GP companies will profit."

Politicians do have a tendency to seize on technology, often prematurely, as the $£ 10$ bn spent a decade ago on the National
Programme for IT showed. The Nuffield Trust's chief executive, Nigel Edwards (10.1136/bmj.i888), says that paperless technology is now at the stage where it can revolutionise healthcare and outlines four lessons from previous rollouts. His conclusion? Involve clinicians to avert a digital disaster.

Technology's revolutionary influence was also felt last week when the owners of the UK newspaper the Independent announced that it would cease daily print publication after 30 years. Its former editor Andrew Marr ${ }^{2}$ said that the move to an online only format marked the loss of a community of "similarly minded, but not identically minded, people who argue, debate and together fashion a view of the world which is distinctive." The BMJ's experience is that such communities straddle both print and online, which Marr would see if he read the open letter (10.1136/bmj.i563) from 83 academics from 12 countries and our response to it (10.1136/bmj.i641). The authors are challenging the journal's policy on qualitative research. Join the live (and lively) debate as it unfolds, digitally of course, on thebmj.com.

Black cab protest: London gridlocked by taxi demonstration against Uber Wednesday Evening Standard $10 \mathrm{Feb} 2016$ www.standard.co.uk/news/transport/black-cab-protestcabbies-set-to-bring-gridlock-to-central-london-with-demonstration-against-uber-a3176746. html

2 Marr A. The loss of the Independent means the loss of a community. Guardian $13 \mathrm{Feb}$ 2016 www.theguardian.com/media/2016/feb/13/the-independent-gave-me-some-of-themost-exciting-times-of-my-career

Published by the BMJ Publishing Group Limited. For permission to use (where not already granted under a licence) please go to http://group.bmj.com/group/rights-licensing/ permissions 